\title{
MANIFESTATION OF SOCIAL IDENTIFICATIONS OF WOULD-BE PHYSICAL EDUCATION AND SPORTS SPECIALISTS
}

Diana Karanauskienė, Kęstutis Kardelis

\author{
Lithuanian Academy of Physical Education, Kaunas, Lithuania
}

\begin{abstract}
Diana Karanauskienè. PhD candidate in Social Sciences (Educational Science) at the Department of Languages, the Lithuanian Academy of Physical Education. The field of scientific research - students' identification with higher school, qualitative research methodology.

ABSTRACT

Research deals with the problem what social identifications are characteristic of the higher school students and how they are related to other factors influencing them. Research object was the social identifications of students. Research aim was to characterize the manifestation of social identifications of would-be physical education and sports specialists and to reveal their links with the independent variables of the research. Research participants were 622 $1-4^{\text {th }}$ year students of the Lithuanian Academy of Physical Education, the faculties of Sports Education and Sports Technologies. The social identifications of students were measured using M. Hooper (1976) Social Identification Measurement Scale. The factor analysis of social identifications distinguished five factors. Social identifications typical of would-be specialists of physical education and sports were linked to social prestige (wish to have a wellpaid job and be respected in the society), family (the roles of husband / wife, father / mother), age (importance of being adult), nationality (importance of being Lithuanian) and political activity (wish to belong to or support a political party). The distinguished social identifications were related to gender (girls compared to boys want more to be adults, but their national identification is weaker), academic achievements (higher achieving students are more identified with family, and it is more important for them to be adults), sports activities (students higher achieving in sports are more identified with their nationality) and other sociodemographic indicators (better-off students want to be adults more, and national identification is more important to those students whose parents are blue-collar workers and farmers compared to the children of white-collar workers).
\end{abstract}

Keywords: social identifications, higher education, Social Identification Measurement Scale.

\section{INTRODUCTION}

0 tudies at a higher school are critical for the development of students' social identities (ASHE-ERIC Higher Education Report, 2002). This can be confirmed by the changes in their self-perception. From the intuitive sense of development which occurs during late adolescence individuals create a sense of self that usually feels more grounded and stable. Answering the question "Who am I?" is paramount to them and requires a substantial amount of reflection and action to try out new behaviors, consider alternative value sets, and become comfortable with the new roles students both take on and are given.

Assessing those changes students begin to understand the multiple layers of identity they have to manage, develop, and make peace with. As all members of the society students undergo many forces and influences of different cultures. Besides the university environment the development of their social identities can be conditioned by various non-traditional contexts: virtual reality, forms of electronic environment and others. However, it does not mean, that 
traditional elements of the development of social identities (family, nation, educational institutions, etc.) do not carry weight. Those particular social categories form the fundamental of the person's social identity.

Thus, it may seem that successful social identification, as P. Heaven (1999) maintains, can provide support to people in the chaotic world and help them make sense of the immense cultural space. Therefore research about the influence of the new (academic) environment on the development of social identifications of young people is critical as it can reveal the peculiarities of the study processes at the institutions of higher education. It is important to note that not much research has been done in the area of social identifications (as constituents of social identity) in connection with the studies in higher education. More research has been addressed to students' academic identity (Osborne, 1997; Howard, 2003; Karanauskiene, Kardelis, 2005) and national identity (Antiniené, 1999, 2002; Ezell et al., 2003; Zevin, 2003; Dolby, 2004). Thus the research question is: what social identifications are characteristic of higher school students and how they are related to other factors influencing them.

In search of answers to those questions two hypotheses were raised:

$\mathrm{H}$ 1. Student population in a higher school is diverse not only by their sociodemographic characteristics, but also by distinctive social identifications.

H 2. The most significant social identifications of students are related to their studies and sociodemographic factors.

Research object was the social identifications of students.

Dependent variables of the research were the manifestations of social identifications of students. Students sociodemographic characteristics, academic achievements and sports activities were chosen as independent variables.

Research aim was to characterize the manifestation of social identifications of would-be physical education and sports specialists and to reveal their links with the independent variables of the research.

The analysis of the conception of social identifications and social identity. Due to rapid social changes social identifications of people become even more important. This is understandable, as knowing how people identify themselves with certain positions in their social life and what values are their priorities in the process of socialization helps us reveal the real life of the society, its groups and various people, and foresee the preconditions and possibilities for making social decisions at different levels of life (Mitrikas, 1995). It is also natural, that social identifications of young people and their research attract more and more attention because the stronger is the identification with a certain social group, the greater is the possibility that the person will take over its behavior standards and values.

A significant part of human social identity is the social roles that are most important to a person at certain period of his / her life (Broom et al., 1992). For example, being a son and a daughter is a very important element of family identification for every boy and girl, as for many other people, however, only being in a social group (family, peer group, local community, nation, etc.) does not guarantee person's social identity. Gender identification, i. e. perceiving oneself as male or female, appears rather early and might be an essential element of person's social identity, but this perception can be more important than other social identifications only at certain periods of life.

The concepts of social identity and social identification are closely interconnected, but they are not identical. Some authors (Gouveia et al., 2002) suggest that social identification emerges when a person admits belonging to a certain social group, and social identity means proximate coalescence with this group. Thus, social identity externalizes subordination of personal needs and interests towards a certain group.

Very often the constructs of social identity and identification converge, most likely they differ from each other conceptually (notionally), and not empirically. The previously mentioned authors suggest that social identification is understood by many scholars as part of social identity, i. e. it depicts the degree the person identifies with certain social groups or categories. On the other hand, person's social identity, which is made from his / her identifications with various social groups, situations and roles, is only a relatively stable condition because situations in human life, especially in young people's life, constantly change, so their social identities are not 
permanently fixed. It means that in research social identity must be viewed not as a state, but as a process of its formation (Krukauskienè et al., 2003).

Social identity fluctuates when a person learns new social roles or when the content of his / her present roles changes. On the other hand, social roles depend on the personal attitudes and values, which constitute the content of social identifications (Broom et al., 1992). Before becoming the President of the United States, Lindon B. Johnson described himself in the following way: "I am a free man. American, a US senator, and - to keep the right order - a democrat. I am also a liberal, conservative, Texas resident, tax payer, ranch owner, businessman, client, parent, voter, and not as young as I used to be, but not so old as I hope to become, and I am all of them but not in turn" (Broom et al., 1992, 79). Thus, in different social spheres one and the same person can be in different stages and environments of identification, where he / she may have to overcome various crises of life and indefinite situations so characteristic of postmodern epoch (Krukauskienè et al., 2003).

\section{RESEARCH METHODS}

Research participants. Research participants were $6221-4^{\text {th }}$ year students of the Lithuanian Academy of Physical Education, the Faculties of Sports Education and Sports Technologies (366 males and 256 females) (the whole population).

Research methods. Students' social identifications were measured with a scale composed by M. Hooper (1976). As S. Greene suggests (2002), social identification measurement needs theoretically firm and psychologically grounded instruments. They should team up with the social-psychological conceptions of group identification. The dominant social-psychological theory which helps to understand the relationship between people and their social groups is the social identity theory. According to it social identification is defined as part of individual's self-concept which derives from his / her knowledge of his / her membership of a social group or groups together with the value and emotional significance attached to that membership (Tajfel, 1981). That is, social identification is based not on the formal, but on the perceived membership in a certain social category, e. g. not every man or woman appreciates his / her social gender.

The instrument which was applied to measure students' social identity had to tap identifications with various social groups significant to them. M. Hooper (1976) suggests that the key phrase "think of yourself as" should constitute the core of the measurement procedure. For example, "generally speaking, do you think of yourself as a liberal ...or not belonging to any political party?". Later on this phrase was incorporated into a verbal format that would tap identifications with a broad range of groups and, at the same time, allow the expression of intensity of identification. For example, "Is it important to you to think of yourself as a [group name placed here]?":

very important, quite important, somewhat important, I don't know, not important.

The use of response categories emerged from a number of informal interviews with students.

If we wanted to measure the social identifications of a number of students with a single instrument so that we could systematically examine their relationship with other variables, we needed that subsets of students within a sample of respondents identified with at least some of the same groups. This procedure would reveal social identification factors, characteristic of the research participants.

Another important step in the construction of the instrument was the selection of stimulus groups. On the basis of the previous research data (Hooper, 1982; Jones, 1997; ASHE-ERIC Higher Education Report, 2002), the following social categories (groups) were distinguished: nationality, gender, age, political activity, social class, family, studies, and work groups. Each social category was incorporated into a question, understandable to research participants. As individual's social identity consists of negative identifications as well, a number of reference groups were included in the negative format, e. g. "Is it important to you to think of yourself as not being a...?" The choice of social groups and the comprehensibility of questions were checked in the interview with nine students. It allowed including more reference groups into the questionnaire (Table 1).

The internal consistency - Cronbach's alpha - of the social identification scale was adequate (0.77). It means that the method was valid to measure social identifications. Every 


\begin{tabular}{|c|c|c|}
\hline Table 1 . Social identifications and & Social identifications & Reference groups \\
\hline & Age identification & $\begin{array}{ll}\text { - } & \text { Adult } \\
\text { - } & \text { Not a child } \\
\text { - } & \text { Adolescent }\end{array}$ \\
\hline & Gender identification & - Man / woman \\
\hline & Family identification & $\begin{array}{ll}\text { - } & \text { Daughter / son } \\
\text { - } & \text { Father / mother (parent) } \\
\text { - } & \text { Husband / wife }\end{array}$ \\
\hline & Identification with studies & $\begin{array}{l}\text { - Higher school student } \\
\text { - } \quad \text { Secondary school graduate } \\
\text { - } \quad \text { Active participant in students' life }\end{array}$ \\
\hline & Identification with political activities & 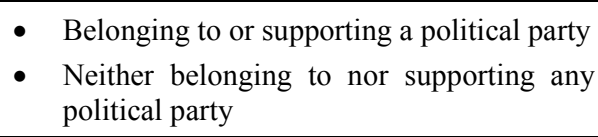 \\
\hline & National identification & $\begin{array}{ll}\text { - } & \text { Lithuanian } \\
\text { - } & \text { Not a foreigner }\end{array}$ \\
\hline & Occupational identification & $\begin{array}{l}\text { - White-collar worker } \\
\text { - } \quad \text { Blue-collar worker }\end{array}$ \\
\hline & Other identifications & $\begin{array}{ll}\text { - } & \text { Well-off } \\
\text { - } & \text { Poor } \\
\text { - } & \text { Middle class } \\
\text { - } & \text { Having a prestigious job } \\
\text { - } & \text { Having a well-paid job } \\
\text { - } & \text { Respected society member }\end{array}$ \\
\hline
\end{tabular}

statement was estimated on a five-point scale. The points were calculated so that the highest number (5) showed the most intense characteristics ("very important"). After estimating each statement in points, the mean showing the intensity of each student's social identification was calculated. Other questionnaire questions were meant to evaluate students' sociodemographic indicators, academic achievements and environmental variables. Students' academic achievements were self-reported measures.

Research procedures. Data collection occurred during the Spring Term, March-May, 2004. The survey was conducted following goodwill, legal and ethical principles. All the research participants were informed that the aim of the survey was to establish how people viewed and identified themselves with the given social categories. They were instructed to go through the list of statements and to put a checkmark in the slot on the scale beneath each item that best corresponded to their feelings.

Statistical analysis. The statistical analysis of the research data was performed using program package SPSS 11.0 for Windows. The methods of descriptive statistics were used to estimate numerical characteristics (mean, standard error, etc.) of various indicators. With the help of parametric and non-parametric methods the hypotheses about the equality of the means of test scores, the significance of the correlation coefficients, the compatibility of the sum of scores distribution with the normal distribution, etc., were tested. To test those hypotheses the factor analysis was performed, Chi square criteria were used, Cronbach's alpha coefficient was calculated. The results were considered statistically significant with the probability level $p<0.05$ and the reliability of 95 per cent.

\section{RESEARCH RESULTS}

The factor analysis of the social identification scale revealed five factors with the eigenvalues of 1.0 or better (Table 2 ).

Thus, from original diagnostic variables five ultimate scales were obtained. As G. Merkys et al. (2001) suggest, extracted factors reflect the multiplexed statistical relation of variables, which can be interpreted as the internal structure of the diagnosed construct. If the factor analysis exposes a notionally meaningful structure, this fact can be 


\begin{tabular}{|c|c|}
\hline \multicolumn{1}{|c|}{ Factors } & Factor loadings \\
\hline I - social prestige & $\mathbf{0 . 7 0}$ \\
- Having a prestigious job & 0.80 \\
- Having a well-paid job & 0.79 \\
- Respected society member & 0.66 \\
- Higher school student & 0.52 \\
\hline II - family & $\mathbf{0 . 6 6}$ \\
- Husband / wife & 0.84 \\
- Father / mother (parent) & 0.78 \\
- Son / daughter & 0.56 \\
- Man / woman & 0.47 \\
\hline III - age & $\mathbf{0 . 8 3}$ \\
- Adult & 0.84 \\
- Not a child & 0.83 \\
\hline IV - nationality & $\mathbf{0 . 6 0}$ \\
- Not a foreigner & 0.72 \\
- Lithuanian & 0.54 \\
\hline V - political activity & $\mathbf{0 . 7 1}$ \\
- Belonging to or supporting a political party & 0.71 \\
- Neither belonging to nor supporting any political party & 0.70 \\
\hline
\end{tabular}

Table 2. Social identifications of would-be physical education and sports specialists

considered as an argument of the validity of the construct and the scale. V. Čekanavičius and G. Murauskas (2002) maintain that the variables of each group are consolidated by a directly indiscernible (latent) factor. The data in Table 2 indicate that the feature uniting the variables of the first factor (factor loading is 0.70 ) is social prestige. The students of this subgroup tend to identify themselves with white-collar workers having prestigious jobs $(0.80)$. It is very important for them to be well-paid (0.79) and be respected in the society (0.66). It should be noted that those are the students who appreciate their studies at a higher school (0.52). That is to say, studying at a higher school is related to the possibility to have a well-paid prestigious job and be respected in the society. It is worth noticing that the evaluation of prestige depends on the respondents' gender. Prestige is more important to female students than to male students (the intensity of the feature $2.70 \pm 0.07$ and $2.37 \pm 0.06$ respectively; $\left.\chi^{2}=13.79 ; d f=3 ; \mathrm{p}<0.01\right)(\mathrm{df}-$ degrees of freedom). This factor was influenced neither by the students' living place, parental education, nor by their social status. Marital status and perceived material standing were not significant, as well.

The unifying feature of the second factor is family (factor loading is 0.66). The students of this subgroup mostly appreciate the social role of husband / wife (feature loading 0.84). It is also important for them to be a parent $(0.78)$ and a son / daughter $(0.56)$. The social gender role identity appears in this factor, as well, but its loading is not high (0.47). The gender differences were not found, i. e. family is equally important to both boys and girls in this population. However, this factor is more significant to married and cohabitant students, compared to single students (respectively $2.86 \pm 0.05$ and $2.44 \pm 0.09$; $\left.\chi^{2}=22.30 ; d f=9 ; \mathrm{p}<0.01\right)$. Identification with family is more important to students who do not have to pay for their studies (respectively $2.58 \pm 0.05$ and $2.33 \pm 0.09 ; \chi^{2}=15.67 ; d f=6$; $\mathrm{p}<0.05)$ and to those whose grades at the secondary school were very good and excellent compared to students whose grades were good and satisfactory (respectively $2.75 \pm 0.12$ and $\left.2.48 \pm 0.05 ; \chi^{2}=13.36 ; d f=6 ; \mathrm{p}<0.05\right)$.

The third factor can be characterized as identification with age, perception and evaluation of one's own age. The factor loading is rather high -0.83 . Students belonging to this subgroup think it is very important for them to be adults (0.84), and not children (0.83). This attitude is more characteristic of girls compared to boys $\left(2.75 \pm 0.07\right.$ and $2.34 \pm 0.11 ; \chi^{2}=20.69 ; d f=3$; $\mathrm{p}<0.001$ ). Being grown-up is more important to students who think they live better than the 
majority of people in Lithuania, compared to those who think that they live worse than many Lithuanians $(2.64 \pm 0.09$ and $1.77 \pm 0.28$; $\left.\chi^{2}=20.87 ; d f=9 ; \mathrm{p}<0.05\right)$, and those who do not have to pay for their studies $(2.57 \pm 0.05$ and $\left.2.34 \pm 0.09 ; \chi^{2}=18.52 ; d f=6 ; \mathrm{p}<0.01\right)$. It is interesting to note that students with higher degree of academic identity tend more to consider themselves as grown-ups than those students whose academic identity is lower $(2.60 \pm 0.06$ and $\left.2.38 \pm 0.06 ; \chi^{2}=9.73 ; d f=3 ; \mathrm{p}<0.05\right)$.

The fourth factor is identification with nationality (0.60). It is significant for students not to be foreigners $(0.73)$, but to be Lithuanians (0.54). In this case national identification is not as important to girls as it is to boys $(2.33 \pm 0.07$ and $\left.2.61 \pm 0.05 ; \chi^{2}=9.87 ; d f=3 ; \mathrm{p}<0.05\right)$. It is worth noting that the social standing of students' parents can also impact their national identification. Students whose parents are bluecollar workers and farmers are more identified with nationality than the children of white-collar workers $\left(2.68 \pm 0.06\right.$ and $2.37 \pm 0.05 ; \chi^{2}=31.19$; $d f=18 ; \mathrm{p}<0.05)$. It should also be noted that national identification is more significant to students who strive for high sports results compared to students who are contented with compulsory sports classes at the academy $\left(2.63 \pm 0.15\right.$ and $2.26 \pm 0.12 ; \chi^{2}=20.71 ; d f=6$; $\mathrm{p}<0.01)$.

The fifth factor can be called political activity (0.71). The students of this subgroup think it is important for them to belong to or to support a certain political party (0.71), not supporting other political forces $(0.70)$. The distinguishing feature of this factor is that it is not related to any other research variable.

\section{DISCUSSION}

Research results indicated that students' identifications with social groups and social roles in those groups can be distributed into clearly identifiable subgroups, which constitute the background of their general social identity. Thus, the results suggest that those factor analyzed subgroups reflect the links of a person and the surrounding environment, whereas the investigation of the identification with one social group would not let us reveal such links. Thereby the present research enabled us to distinguish five types of students' social identifications in the researched population, and those identifications were mostly related to work (learning) and family. This can be confirmed by the research of other authors. M. Hooper (1982) studied social identifications in different populations (lawyers, housewives, scientists, etc.) and found that the most intense social identifications were the same (work and family), while the intensity of other social identifications, such as ethnic, religious and others, was miscellaneous or low. So, we suggest that the factors distinguished in this research could be characteristic of other groups of students, as well. However, M. Hooper (1982) implies that it is advisable to estimate the social identifications of each population at each period of time anew.

It is worth noticing the research data indicating that girls value social prestige in their future work more than boys. This can be explained by the fact that women are more sensitive about that, because in spite of the positive changes in the sphere of gender equality during the last decades there are still differences in the possibilities for men and women to get a better-paid job or be financially motivated, to gain access to the organizational capital and information resources which are necessary for the professional development (Timberlake, 2005). Other authors (Simpson et al., 2005) uphold that men think they need knowledge and skills in their jobs, but women assume it is more important for them to be listened to and their opinion to be taken into account.

It is understandable that after starting studies at a higher school students' identifications with their age mediate. Due to changing living conditions and the nature of studies, the period of coming of age, students start a new stage in their lives - the lives of adults, and for every person the beginning of a new epoch of life is very important. Therefore much research has been carried out with the aim not only to reveal the manifestation of identification of young adults with their age, but also to estimate its role and influence on people's life (McCann et al., 2004). In the context of our study more research is needed to explain why in the population of would be specialists of physical education and sports becoming adults is more important to girls than to boys, and to students with a higher degree of academic identity (usually they learn better and do not have to pay for their studies), as well as to those who think they live better than the majority 
of people in Lithuania. Family identification of young people should also interest researchers because family plays a very important role in young people's lives. Other studies provide data about the links between intense family identification and self esteem, psychological wellbeing (Reitzes, Mutran, 2004), as well as academic achievements and career (Hall, 2003). Those links were traced in our research, too, besides it was noticed that identification with age increased among students having families of their own.

In the context of the academy the fact that stronger national identification is more characteristic of those students who strive for high sports results compared to students who are not actively engaged in sports is of great importance. The relationship between sports and national identification has been studied in other research, as well (Bainer, 2003; Poulton, 2004; Stankovič, 2004), where sports achievements, especially in popular branches of sports, were also associated with increasing pride in one's nation, as well as national identification of sportsmen and fans. Besides, in our research national identification is more typical of boys, because they strive for sports results more than girls, consequently their sports identity is of a higher degree.

Other researchers (Broom et al., 1992), having studied students' identifications for more than three decades, noticed that students' social identifications turned from institutional orientations towards personal orientations. According to their research data, in the fifties and sixties the students identified themselves with familiar social roles, society aims and social group responsibilities. Thus they described themselves according to their student position, religion or family status. At present students tend to identify themselves according to their feelings and experiences. The data of our research did not confirm those tendencies. The majority of our research participants exposed traditional social identifications, connected with social standing and family.

\section{CONCLUSIONS}

1. The present research indicated that social identifications typical of would-be specialists of physical education and sports were linked to social prestige (wish to have a well-paid job and be respected in the society), family (the roles of husband / wife, father / mother), age (importance of being adult), nationality (importance of being Lithuanian) and political activity (wish to belong to or support a political party).

2. The distinguished social identifications were related to gender (girls compared to boys want more to be adults, but their national identification is weaker), academic achievements (higher achieving students are more identified with family, and it is more important for them to be adults), sports activities (students higher achieving in sports are more identified with their nationality) and other sociodemographic indicators (better-off students want to be adults more, and national identification is more important to those students whose parents are blue-collar workers and farmers compared to the children of whitecollar workers).

\section{REFERENCES}

Antinienè, D. (2002). Asmens tautinio tapatumo tapsmas. Sociopsichologinès šio proceso interpretacijos. Sociologija. Mintis ir veiksmas, 2, 100-107.

Antinienè, D. (1999). Tautinè tapatybè kaip vienas iš asmens tapatumo aspektu. Psichologija, 20, 41-50.

ASHE-ERIC Higher Education Report. (2002). Internet link: http://web9.epnet.com

Bainer, A. (2003). Political unionism and sporting nationalism: An examination of the relationship between sport and national dentity within the Ulster unionist tradition. Identities, 10 (4), 517-536.

Broom, L., Boujen, C., Broom, D. (1992). Sociologija: esminiai tekstai ir pavyzdžiai. Kaunas: Litera Universitatis
Vytauti Magni.

Čekanavičius, V., Murauskas, G. (2002). Statistika ir jos taikymai. II. Vilnius: TEV.

Dolby, N. (2004). Encountering an American Self: Study abroad and national identity. Comparative Education Review, 48 (2), 150-174.

Ezell, E. D., Seeleib-Kaiser, M., Tiryakian, E. A. (2003). National identity issues in the new German elites: A study of German university students. International Journal of Comparative Sociology, 44 (4), 280-309.

Gouveia, V., De Albuquerque, J., Clemente, M., Espinosa, P. (2002). Human values and social identities: A study in two collectivist cultures. International Journal of Psychology, 
37 (6), 333-342.

Greene, S. (2002). The social-psychological measurement of partisanship. Political Behavior, 24 (3), 171-197.

Hall, A. S. (2003). Expanding academic and career selfefficacy: A family systems framework. Journal of Counseling and Development, 81, 33-39.

Heaven, P. (1999). Group identities and human values. Journal of Social Psychology, 139, 590-595.

Hooper, M. (1982). Explorations in the structure of psychological identifications with social groups and roles. Multivariate Behavioral Research, 17, 515-523.

Hooper, M. (1976). The structure and measurement of social identity. Public Opinion Quarterly, 40 (2), 154165.

Howard, T. C. (2003). „A tug of war in our minds”: African American high school students' perceptions of their academic identities and college aspirations. High School Journal, 87 (1), 4-18.

Jones, S. (1997). Voices of identity and difference: A qualitative exploration of identity development in women college students. Journal of College Student Development, 38 (4), 376-386.

Karanauskienè, D., Kardelis, K. (2005). The relationship between students' academic identity and academic achievements. Socialiniai mokslai, 1 (47), 62-70.

Krukauskienė, E., Trinkūnienė, I., Žilinskaitè, V. (2003). Jaunimo kultūrinis identitetas: prioritetai, nuostatos, etnine kultūra (monografija). Vilnius: Eugrimas.

McCann, R., Kellermann, K., Giles, H., Gallois, C., Viladot, M. A. (2004). Cultural and gender influences on age identification. Communication Studies, 55 (1), 88106.

Merkys, G., Purvaneckienė, G., Ruškus, J., Kazlauskaitè, I.
(2001). Lytiškumo stereotipų raiška Lietuvos mokytojų ir mokiniu populiacijose: apklausos raštu duomenys. Lytiškumas ir švietimas: pažiūru, stereotipu ir ugdymo turinio tyrimai (pp. 69-107). Šiauliai: ŠU.

Mitrikas, A. A., (1995). Socialinis identifikavimasis ir laiko naudojimas. Permainu metas: Tapatumo ieškojimas. Vilnius. P. 45-55.

Osborne, J. W. (1997). Identification with academics and academic success among community college students. Community College Review, 25 (1), 59-69.

Poulton, E. (2004). Mediated patriot games: The construction and representation of national identities in the British television Production of Euro'96. International Review for the Sociology of Sport, 39 (4), 437-456.

Reitzes, D. C., Mutran, E. J. (2004). Grandparent identity, intergenerational family identity, and well-being. Psychological Sciences and Social Sciences, 59 B (4), S 213-220.

Simpson, R., Sturges, J., Woods, A., Altman, Y. (2005). Gender, age, and the MBA: An analyses of extrinsic and intrinsic career benefits. Journal of Management Education, 29 (2), 218-248.

Stankovič, P. (2004). Sport, nationalism and the shifting meanings of soccer in Slovenia. European Journal of Cultural Studies, 7 (2), 237-254.

Tajfel, H. (1981). Human Groups and Social Categories. Cambridge: Cambridge University Press.

Timberlake, S. (2005). Social capital and gender in the workplace. Journal of Managenment Development, 24 (1), 34-45.

Zevin, J. (2003). Perceptions of national identity: How adolescents in the United States and Norway view their own and other countries. Social Studies, 94 (5), $227-$ 232.
Received on May 11, 2005

Accepted on June 30, 2005
Diana Karanauskienè

Lithuanian Academy of Physical Education Sporto str. 6, LT-44221 Kaunas

Lithuania

Tel +370 37302663

E-mail d.karanauskiene@1kka.lt 